\author{
JOSEF ŽEMLIČKA \\ Historický ústav Akademie věd \\ České republiky
}

\title{
EUROPA ŚRODKOWA I JEJ WCZESNE PAŃSTWOWOŚCI: TEMAT WYCZERPANY CZY PERSPEKTYWICZNY?
}

Europę Środkową można definiować na różne sposoby: geograficznie, historycznie, politycznie. Czasem mówi się o Europie Środkowo-Wschodniej, o wschodniej części Europy Środkowej (Ostmitteleuropa) lub o Europie Wschodniej, sięgającej aż po Łabę. Jednak dla badacza procesów powstawania średniowiecznych państwowości termin Europa Środkowa ma specyficzne zabarwienie. Jak rozwijały się państwa na terytorium Czech, Polski i Węgier, stanowiących jądro „historycznej” Europy Środkowej? Czy wczesne twory państwowe Przemyślidów, Piastów i Arpadów łączyło wystarczająco wiele cech, by można było mówić o ich genetycznym pokrewieństwie, czy też obraz ten jest błędny i trzeba go zastąpić innym wzorem? ${ }^{1}$

Przed ponad półwieczem niektórzy polscy, czechosłowaccy i węgierscy historycy zaczęli zwracać uwagę na podobieństwa Czech, Polski i Węgier. I chociaż nie doszli do pewnych i jednoznacznych wniosków, a w szczegółach często się różnili, udało im się w nowym świetle ukazać powstanie i pierwszą fazę istnienia czeskiego, polskiego i węgierskiego państwa. W swoich obserwacjach odwoływali się do archeologii i językoznawstwa, uwypuklając transdyscyplinarny wymiar problemu.

${ }^{1}$ Z ostatnich opracowań zob. Ch. Lübke, Mitteleuropa, Ostmitteleuropa, östliches Europa: Wahrnehmung und frühe Strukturen eines Raumes, w: Die „Blüte” der Staaten des östlichen Europa im 14. Jahrhundert, red. M. Löwener, Wiesbaden 2004, Deutsches Historisches Institut Warschau. Quellen und Studien, 14, s. 15-43; M. Font, Mitteleuropa Osteuropa - Ost mitteleuropa? Bemerkungen zur Entstehung einer europäischen Region im Frühmittelalter, ,Jahrbuch für europäische Geschichte” 7, 2006, s. 101-125; G. Klaniczay, Vom Ostmitteleuropa zu Westmitteleuropa: Eine Umwandlung im Hochmittelalter, w: Böhmen und seine Nachbarn in der Přemyslidenzeit, red. I. Hlaváček, A. Patschovsky, Ostfildern 2011, Vorträge und Forschungen, 74, s. 17-48. 
Powstało coś, co można by nazwać modelem środkowoeuropejskim. Mniejsza o to, czy jego kształt skrywał się w „ustroju prawa książęcego”, jak pisali polscy badacze, czy też w interpretacji roli władcy i ,jego" państwa u Dušana Třeštíka. W obu przypadkach akcentowano silną władzę centralną, z którą wiązały się zarobki, ciężary i powinności ludności, w dalszej kolejności regalia i monopole, a wszystko to rozdzielone i służące „książęcej" elicie rządzącej, zarodkowi przyszłej szlachty. Europa Środkowa wydawała się wysepką, na której zrodził się nowy, swoisty model rozwoju².

Fala oczarowania Europą Środkową powróciła na początku lat dziewięćdziesiątych minionego wieku. Część reprezentacji politycznej Polski, Czechosłowacji i Węgier podkreślała wspólnotę niedawnych doświadczeń i zbieżne interesy geopolityczne, co ostatecznie doprowadziło do ukonstytuowania tzw. wyszehradzkiej czwórki. Historia sprzed tysiąca lat nie odgrywała już w tych debatach praktycznie żadnej roli, tylko w kręgach historyków niekiedy wskazywano na głębsze przyczyny środkowoeuropejskiej solidarności. Szalejąca burza transformacji zagłuszyła te głosy. O ile w ogóle mówiono o pewnym pokrewieństwie, to raczej o czterdziestoletnim współżyciu w tym samym obozie i o jego próbach politycznej i gospodarczej unifikacji ${ }^{3}$.

Ostatecznie dobrze się jednak stało, że do takiego połączenia historii z polityką nie doszło, że historia nie uzasadniała wstecznie „słuszności" wspólnej drogi. Między rokiem 1000 a 2000 leży bowiem długa epoka pełna zmian, ewolucji, modernizacji i anomalii, w czasie której pierwotne podobieństwo przesłoniły inne dramaty. Zresztą nawet owe wypowiedzi o wspólnych fundamentach nie brzmiały w tamtym momencie unisono. Właśnie od lat dziewięćdziesiątych zaczęły się pojawiać głosy krytyczne. Zwracają one uwagę na silniejsze niż wcześniej przypuszczano realne związki Europy Środkowej z sąsiadem karolińskim, ottońskim i salickim i przestrzegają przed automatycznym przenoszeniem doświadczeń z jednego kraju do innego. To logiczne, wszak również obraz średniowiecznych Niemiec, do którego tradycyjnie porównuje się rozwój Europy Środkowej, zmienił się w tym czasie (choćby w polemikach z książką Susanne Reynolds ${ }^{4}$ i wciąż przechodzi proces istotnych korekt. Wiemy już, jak zwodnicze bywa uproszczone mówie-

${ }^{2}$ Literatura tematu jest olbrzymia, choć w części wymieniają ją D. Třeštík, J. Žemlička, O modelech vývoje premyslovského státu, „Český časopis historický” 105, 2007, s. 122-164, przyp. 1.

${ }^{3}$ Ideowy ferment lat dziewięćdziesiątych znalazł odbicie w felietonach i okolicznościowych wypowiedziach D. Třeštíka, zebranych w tomach: idem: Mysliti dějiny, Praha-Litomyšl 1999; idem, Češi a dějiny v postmoderním očistci, Praha 2005.

${ }^{4}$ S. Reynolds, Fiefs and Vassals. The Medieval Evidence Reinterpreted, Oxford 1994. 
nie o średniowiecznych „Niemczech”, składających się z mgławicy terytoriów, ziem i regionów na różnym stopniu rozwoju. Alzacja i Lotaryngia były czymś zupełnie innym niż Bawaria, Saksonia różniła się od Szwabii, do tego w różnym stopniu działały tam królewskie „prawa” regalne, majątkowe i inne. Barwna paleta kwestii związanych z organizacją wczesnych struktur państwowych Czech, Polski i Węgier została wprawiona w ruch.

Impulsy lat minionych poszerzyły horyzont, ukazując nowe fakty, krytyczniej odczytując źródła i rodząc nowe inspiracje, w sumie jednak nie rozsadziły tezy o pierwotnych podobieństwach linii rozwoju „historycznej" Europy Środkowej. Przede wszystkim często zapomina się o punktach wyjścia. Trudno zaprzeczyć, że proces państwotwórczy, rodzący się na zewnątrz dawnego rzymskiego limes, siłą rzeczy musiał się z początku rozwijać inaczej niż regiony objęte jego cywilizacyjną granicą. Podczas gdy Galia, Nadrenia i bawarska dolina Dunaju budowały na zastanych już, choć podupadłych funkcjach swoich civitates (dość wspomnieć Kolonię, Moguncję, Trewir, Ratyzbonę i in.) i na reliktach późnoantycznych latyfundiów, przestrzeń na północ i wschód od limes ich nie znały. Życie „państwowe” rodziło się tam w surowych warunkach gospodarczych niedostatków i społecznego zacofania. „Nowa” Europa Środkowa stała się ojczyzną plemion słowiańskich, „gentes Sclauorum”, jak o nich w połowie IX w. mówił Geograf Bawarski. Głównym ich zajęciem było rolnictwo i prosta wymiana. O strukturze wewnętrznej owych "plemion" niewiele mamy pewnych informacji. Dopiero później na ich czele widzimy tzw. duces, najpewniej rodzaj naczelników grodów („857 civitas Wiztrachi ducis”)5.Proces unifikacji rozwinął się najszybciej w dolinach morawskich rzek, gdzie już na początku IX w. formują się Wielkie Morawy. Panującym z dynastii Mojmirowiców udało się ukrócić władzę regionalnych wielmożów i stworzyć strukturę zdolną do stawienia oporu ekspansji państwa wschodniofrankijskiego. Za Świętopełka (zm. 894) rozszerzyli swoje wpływy na Czechy, kraj Wiślan $\mathrm{i}$ inne regiony. Równolegle w trakcie IX w. redukcji ulegała liczba słowiańskich duces. Nie uchodzi to uwadze frankijskich i wschodniofrankijskich annałów, interesujących się głównie eksponowanym czeskim sąsiadem. Podczas gdy w roku 845 mówi się o „XIIII ex ducibus Boemanorum”, w roku 872 nazwa ta obejmuje tylko sześciu, a w roku 895 roczniki z Fuldy wspominają o „wszystkich książętach Czechów”, wśród których najważniejsi są dwaj. Analogiczne procesy zachodziły na ziemiach polskich. Przemyślidzi i Piastowie otaczali swoje pierwotne domeny, czy też „patrymonia” wokół Pragi i Gniezna systemem grodów, zmieniając je w jądra krystalizacji

${ }^{5}$ Annales Fuldenses, wyd. F. Kurze, MGH SrG, Hannoverae 1891, s. 47. 
przyszłych organizmów „państwowych”. Nieocenioną pomoc w badaniu tych właśnie procesów stanowią prace archeologów ${ }^{6}$.

od kiedy jednak można mówić o „państwie”, czy też jego zarodku? Również to pytanie jest częścią dyskusji o rozwoju Europy Środkowej.

W literaturze zachodniej, głównie niemieckojęzycznej, trwa dyskusja, czy nie należałoby w stosunku do wczesnego średniowiecza ograniczyć terminu „państwo” lub go wyeliminować. Powraca pytanie, czym właściwie były germańskie regna. Postulat jasnej terminologii trudno pogodzić z ograniczonym słownictwem. Dyskusje nad europejskim modelem rozwoju mają przy tym silny akcent okcydentalny. Uwzględniają „postępowe” części kontynentu europejskiego, gdzie rodzić się miały perspektywiczne trendy, choć proces formowania Czech, Polski i Węgier (ale także Rusi Kijowskiej) skłania do kolejnych modyfikacji. Szczególnie ich początki wymagają użycia różnych form opisu, wyrażających ich ówczesną niestabilność i słabość, brak pewnego miejsca na politycznej mapie regionu. Dobrze wiemy, czym różniły się owe organizmy od swoich skonsolidowanych następców i jak dalece państwo średniowieczne odbiegało od swojego nowoczesnego odpowiednika; świadomość ta jednak nie ułatwia rozwiązywania terminologicznych rebusów. Z pełną świadomością tego ryzyka naszą syntezę okresu panowania Przemyślidów opatrzyliśmy tytułem Přemyslovci. Budování českého státu (red. P. Sommer, D. Třeštík, J. Žemlička, Praha 2009)7.

Więcej trudności wiąże się z pytaniem, jak funkcjonowały wczesne monarchie Przemyślidów, Piastów i Arpadów. Co jeszcze zachowało aktualność z czasu, gdy Karol Buczek, Karol Modzelewski, D. Třeštík, Matúš Kučera odnajdywali wspólne rysy ich mechanizmów? Z czego zaś trzeba będzie dziś, pod wpływem kolejnych rewizji, zrezygnować?

Co znamienne, wszystkie te twory z jednej strony znajdowały się na zewnątrz rzymskiego limes i nie mogły bezpośrednio czerpać z tradycji pro-

${ }^{6}$ Podsumowanie tego problemu dał już Henryk Łowmiański (idem, Początki Polski, 4-5, Warszawa 1970-1973), na przykładzie Czech Josef Žemlička (idem, „,Duces Boemanorum” a vznik premyslovské monarchie, „Československý časopis historický” 37, 1989, s.697-721). O dawnej domenie Przemyślidów i Piastów pisali Jiři Sláma i Zofia Kurnatowska, poszerzając obraz o słowiańskie „państwa” Europy Środkowo-Wschodniej i Południowo-Wschodniej. I. Sláma, Střední Čechy v raném středověku, t. 3: Archeologie o premyslovského státu, Praha 1988; Z. Kurnatowska, Formowanie się państw słowiańskich w aspekcie porównawczym, w: Europa barbarica, Europa Christiana. Studia mediaevalia Carolo Modzelewski dedicata, red. R. Michałowski et al., Warszawa 2008, s. 81-91; ostatnio Z. Kurnatowska, M. Kara, Wczesnopiastowskie regnum - jak powstało i jaki miało charakter? Próba spojrzenia od strony źródeł archeologicznych, „Slavia Antiqua” 101, 2010, s. 23-96.

${ }^{7} \mathrm{Z}$ nowych tytułów programowych: Staat im frühen Mittelalter, red. A. Airlie, W. Pohl, H. Reimitz, Wien 2006, Forschungen zur Geschichte des Mittelalters, 11; W. Pohl, V. Wieser, Der frühmittelalterliche Staat - europäische Perspektiven, Wien 2009, Forschungen zur Geschichte des Mittelalters, 16. 
wincjonalnych imperium (wyjątek stanowi centralna część dawnej Panonii), z drugiej zaś strony utrzymywały ożywione kontakty z politycznym centrum Rzeszy, czyli z Bawarią, a następnie Saksonią. Do tego dochodzi cały szereg kolejnych wspólnych cech. Polska i Czechy były sobie przy tym bliższe niż wzorzec węgierski, przeniknięty przez żywioł staromadziarski.

Uderzająca jest przywódcza rola tamtejszych dynastii założycielskich. Mało gdzie ich dominacja była tak wyraźna. Pozostawiając na marginesie dyskusje o granicach książęcego absolutyzmu, odgrywające zasadniczą rolę zwłaszcza w historiografii polskiej, poza sporem pozostaje, iż Przemyślidzi, Piastowie i Arpadowie skutecznie wpoili swemu „ludowi” ( populus) zasadę, zgodnie z którą przysługuje im dziedziczne, właściwie „na wieki”, prawo do władzy. Swoje regna postrzegali zrazu jak własność prywatną, administrowaną za pośrednictwem rządców i urzędników. Ale praktyka była bardziej złożona, od początku musieli sobie radzić z owymi comites, nobiles, proceres. Kiedy opozycyjni wielmoże dążyli do zmiany panującego, na czele buntu stawiali zawsze jedynie dysydentów z grona charyzmatycznych rodzin panujących. Impuls książęcy zadecydował też o formalnym przyjęciu wiary chrześcijańskiej, nieodłącznie towarzyszącemu początkom życia państwowego Czech, Polski i Węgier. Niekiedy przymusowa chrystianizacja współgrała z utrwalaniem „dyscypliny państwowej” (nakaz Bolesława Chrobrego o dotrzymywaniu postu, dekrety Brzetysława I). Także pierwsi dynastyczni święci (Czechy, Węgry) legitymizowali i sakralizowali „wieczne” panowanie rodów założycielskich ${ }^{8}$.

Nie brak i innych zbieżności, typowych dla Europy Środkowej. Po „ukonstytuowaniu” wszystkie trzy wczesne monarchie przebyły drogę, którą w skrócie można ująć w słowach „powstanie - ekspansja - kryzys - odnowa", choć niektóre fazy zachodziły w poszczególnych krajach z opóźnieniem rzędu jednego - dwóch pokoleń. Po okresie terytorialnej ekspansji, kiedy granice „państwa” czeskich Bolesławów zbliżyły się do Rusi Kijowskiej, Czechy przeżyły załamanie około roku 1000. Polska znalazła się w analogicznej fazie po śmierci Bolesława Chrobrego (1025), a Węgry za następców św. Stefana (1038). Czysty przypadek? W żadnym razie - był to kryzys systemowy, typowy dla młodych państw Europy Środkowej, potrafiących na pierwszym etapie zapewnić sobie wzrost i stabilizację jedynie za pomocą łupieżczej ekspansji zewnętrznej. Po

${ }^{8}$ O znaczeniu chrystianizacji dla Środkowej i Wschodniej Europy w ujęciu porównawczym: Christianization and the Rise of Christian Monarchy. Scandinavia, Central Europe and Rus' c. 900-1200, red. by N. Berendt, Cambridge 2007; o jednoczącej roli „świętych" książąt i królów: G. Klaniczay, Holy Rulers and Blessed Princesses. Dynastic Cults in Medieval Central Europe, Cambridge 2000. 
wyczerpaniu jej potencjału następował ostry regres, któremu towarzyszył również kryzys dynastyczny, a w Polsce i na Węgrzech nawet „pogańska" reakcja. Dopiero po pokonaniu kryzysu ciężar fiskalny przeniósł się na eksploatację „rodzimych” źródeł, wzmożoną naciskiem na organizację rolnictwa9.

Już przed tymi kryzysami, ale także po nich „odnowione” monarchie stawały wobec pytania, jak w warunkach niskiej wydajności rolnictwa i braku rozwiniętego rynku trwale zabezpieczyć materialne potrzeby „państwa”, czyli księcia, jego otoczenia i w ogóle warstwy rządzącej. Rozwiązanie przyniosła prosta, choć funkcjonalna instytucja, oparta na systemie grodów kasztelańskich. W Czechach i w Polsce mówi się zwykle o organizacji grodowej, kasztelańskiej albo grodowo-prowincjonalnej, na Węgrzech komitackiej (żupnej); w zasadzie chodziło o to samo. Książęcy/królewski „gród” (zwykle civitas, urbs), pierwotnie obdarzony funkcjami militarnymi, przeobraził się w centrum administracyjne, egzekwujące daniny, opłaty i powinności prostego ludu, a jego kościół zajął trwałe miejsce w rodzącej się organizacji kościelnej. Zarządca grodu, zwany comes, praefectus urbis, castellanus, dysponował na „swoim” terytorium sporymi uprawnieniami. Jego urząd stawał się beneficjum, nagrodą panującego dla drużynników i dworzan. Część dochodów kasztelanii (ze względu na powierzchnię kraju, w Polsce kilka kasztelanii stanowiło prowincję) była odprowadzana na potrzeby dworu książęcego, część zostawała do dyspozycji miejscowych urzędników, zarządców, beneficjentów różnych stopni. Rozważając kwestię, czy ten autarkiczny system dystrybucji został przejęty przez młode Czechy, Polskę i Węgry z praktyki Wielkich Moraw, gdzie rozwinął się w oparciu o wzory późnego antyku i karolińskie, jak przypuszczał D. Třeštík, nie wolno lekceważyć także czynników miejscowych, warunkowanych stanem gospodarki z jednej, a technicznymi możliwościami organizacji i potrzebami konsumpcyjnymi nierozwiniętego „państwa” z drugiej strony. „Środkowoeuropejska” nomenklatura łacińska może mylić. Formalnie przejmuje zachodnią terminologię, obfituje jednak w rozmaite przesunięcia znaczeniowe ${ }^{10}$.

${ }^{9}$ Dalsza literatura w: J. Žemlička, Expanze, krize a obnova Čech v letech 935-1055 (K systémovým proměnám raných státu ve střední Evropě), „Český časopis historický” 93, 1995, s. 205-222; idem, Das „Reich“ der böhmischen Boleslavs und die Krise an der Jahrtausendwende. Zur Charakteristik der frühen Staaten in Mitteleuropa, „Archeologické rozhledy” 47, 1995, s. 267-278.

${ }^{10}$ Na ten temat narosła olbrzymia literatura, obszerniej w tym duchu: J. Žemlička, Čechy $v$ době knížecí (1034-1198), Praha 2007, s. 149-187. O pośredniczącej roli wzorów wielkomorawskich pisał wielokrotnie D. Třeštík, np.: idem, Místo Velké Moravy v dějinách. Ke stavu a potřebám bádání o Velké Moravě, „Český časopis historický” 97, 1999, s. 689-727. 
Do zjawisk typowych dla historycznych początków Czech, Polski i Węgier należy tzw. organizacja służebna. Jest to nazwa sztuczna i nowoczesna, podobnie jak wiele innych (choćby system grodów lub komitatów). Powstała z potrzeby opisu faktu, iż w okresie niskiego poziomu produkcji i praktycznej absencji rynku i wymiany pieniężnej młode państwa Europy Środkowej wytworzyły aparat służący ich elementarnym potrzebom materialnym i obsłudze. Jak inaczej zapewnić dworskim i grodzkim elitom ablucje w łaźni, niż nakładając taką powinność na wybranych ludzi, jak inaczej dostarczyć książęcemu wojsku potrzebne mu tarcze, niż składając ten obowiązek na barki specjalistów. I nie jest to niczym nowym, już w starożytnej Mezopotamii odnajdujemy przykład autarkicznego społeczeństwa, w którym część „danin” lub powinności jest odprowadzana na potrzeby dworu lub wojska. Jest to fenomen ponadczasowy, uwarunkowany stanem wymiany i produkcji. Oczywiście dziś nikt już nie broni tezy Hermenegilda Jirečka o całych wsiach służebnych, nazwanych zgodnie z dominującym rzemiosłem lub świadczoną powinnością. Mamy na myśli aparat produkujący i świadczący usługi „na rzecz monarchii”. Pod tym względem wywody K. Buczka, K. Modzelewskiego, D. Třeštíka i ostatnio Christiana Lübkego są w dalszym ciągu przekonywające, bez względu na polemiki, czy system służebny był związany z grodami czy z dworami. Oczywiście całe to zjawisko można by nazwać inaczej. Jeśli określenie „organizacja”, przywołujące obraz porządku i systemu, drażni, wybierzmy sobie inne, znowuż sztuczne określenia, za każdym razem chodzi o to samo. W ograniczonych warunkach wczesnego państwa zjawisko to było obiektywnym faktem, jakkolwiek byśmy je nazwali ${ }^{11}$.

Z perspektywy modelowo zbieżnych pierwotnych podstaw monarchii Europy Środkowej pouczające są również nazwy powinności, danin i trybutów płaconych przez ludność księciu, względnie „państwu”. Szczególnie terminy czeskie i polskie są sobie bliskie, czasami identyczne. Dziś jednak kierujemy uwagę przede wszystkim na wczesną szlachtę i źródła jej pozycji. Choć i tu ścierają się różne stanowiska, porównanie wskazuje, że polityczna siła comites, nobiles czy magnates w Czechach Przemyślidów, piastowskiej Polsce czy na Węgrzech Arpadów nie opierała się z początku na rozległych majątkach ziemskich, lecz na piastowaniu dworskich i grodzkich urzędów i beneficjów. Nie oznacza to, iżby wczesna szlachta w ogóle nie miała dóbr ziemskich, były one jednak niewielkie i rozproszone, a władca w dużym stopniu zachowywał nad nimi zwierzchność. Dopiero

11 Ostatnio: J. Klápště, The Czech Lands in Medieval Transformation, Leiden-Boston 2012, East Central and Eastern Europe in the Middle Ages, 450-1450, 17, s. 344-350, tam również podstawowa literatura, miejscami jednak nieco zbyteczna polemika z odrzuconymi już poglądami. 
w XII i XIII w. sytuacja uległa odwróceniu. Szlachta „beneficjencka” staje się „ziemiańską”, wzmacniając swoją pozycję majątkową za pomocą energicznej akcji kolonizacyjnej. Dopiero wówczas powstają prawdziwe pańskie domeny typu alodialnego, charakterystyczne dla późniejszego średniowiecza. $\mathrm{W}$ procesie strukturalnej transformacji całego społeczeństwa, pod wpływem nowych ram prawnych, przenikających na wschód wraz z zasadą lokacji, prawa niemieckiego i ustroju miejskiego, pierwotny wzorzec środkowoeuropejski został „zdemontowany”, a później w coraz większym stopniu zlewał się z ogólnymi trendami rozwojowymi Europy łacińskiej ${ }^{12}$.

Jakie stąd wynikają wnioski? Nakreślony tu obraz, przybliżający wewnętrzne struktury zwłaszcza Czech i Polski, ma swoich krytyków. Sławomir Gawlas podkreślał militarny charakter najstarszej fazy Polski piastowskiej. Jej dalszy rozwój, zainicjowany przez Kazimierza Odnowiciela w połowie XI w., łączył z adaptacją modelu ottońsko-salickiego i zainspirowanej nim administracji grodzkiej. Dopiero później, w wieku XII, przyjąć się miał system tzw. prawa książęcego. Gawlas położył więc nacisk na ideowy i organizacyjny wpływ niemieckiego sąsiada: efekty przełomu lokacyjnego i jego impulsów modernizacyjnych, zwłaszcza kolonizacji niemieckiej i urbanizacji. Ze strony Piastów podkreślił ożywienie zainteresowania wpływami i dochodami z regaliów. Brak u Gawlasa wzmianki o modelowej harmonii wczesnych Czech, Polski i Węgier ${ }^{13}$.

Ale co zrobić z tyloma objawami zbieżności? Można się zastanawiać, czy ciężary i powinności ludu podległego grodowi miały charakter prawa powszechnego, czy wynikały z własności ziemi panującego. Oba modele się przenikały. Co jednak z modelem środkowoeuropejskiej ścieżki rozwoju, modelem, którego istnieniu się zaprzecza, a mimo to jego krytycy mówią o „podobieństwie niektórych elementów”? Jak to wyjaśniają? Czasami zarzuty trafiają w próżnię. Przecież nikt nie upiera się przy tezie o „totalnej identyczności" wczesnych Czech, Polski i Węgier; także w refleksji modelowej znajdzie się miejsce na rozmaite rozwiązania. W stylu rządzenia, w organizacji funkcji administracyjnych, wojska itp. Nic nie jest podobne jak dwie krople wody, również wewnątrz Czech, Polski, nie mówiąc o ogrom-

${ }^{12}$ Kwestie te są obecnie w Czechach przedmiotem licznych dyskusji, do zwolenników wolnych dóbr szlacheckich i samodzielnej domeny władcy od samego początku państwa Przemyślidów należy Libor. Jan (idem, Václav II. a struktury panovnické moci, Praha 2006, Knižnice Matice moravské, 18) i in., ostatnie jak dotąd słowo drugiej strony: J. Žemlička, K pozemkové výbavě české nobility ve starším středověku, „Český časopis historický" 110, 2012, s. 189-233.

${ }^{13} \mathrm{~S}$. Gawlas, 0 kształt zjednoczonego Królestwa. Niemieckie władztwo terytorialne a geneza społecznoustrojowej odrębności Polski, Warszawa 1996, Studia Humanistyczne, 1, i w licznych innych studiach. 
nych Węgrzech, istniały różnice regionalne. Nikt nie zaprzecza zachodnim wpływom w rozwoju Europy Środkowej, oddziałującym w kilku rzutach. Mimo to można powiedzieć, że powstanie i początkowy okres monarchii Przemyślidów, Piastów i Arpadów wykazywały systemowe podobieństwa, że ich konstrukcja wyrastała z porównywalnych warunków bazowych. Tak właśnie można rozumieć rolę Europy Środkowej w historii kontynentu ${ }^{14}$. Zagadnienie wczesnych państw Europy Środkowej z pewnością długo jeszcze będzie zajmować centralne miejsce w dyskusjach mediewistów. Daleko mu do wyczerpania; zresztą tworzenie modeli zajmuje ważne miejsce w nowoczesnej historiografii. Dlatego też Europa Środkowa naprawdę nie jest jedynie pojęciem geograficznym, lecz również historycznym.

Zjęz.czeskiego przełożył Maciej Górny

${ }^{14}$ Przegląd głównych koncepcji: M.R. Pauk, Recepcja nowych form życia społecznego na Słowiańszczyźnie Zachodniej w dobie „transformacji XIII wieku”, w: Słowiańszczyzna $w$ tworzeniu Europy (X-XIII/XIV w.). Pytania o strategię badań: europeizacja a przełom cywilizacyjny, red. S. Rosik, Wrocław 2008, s. 43-69. 